\title{
DOWN TO EARTH
}

\author{
The Territorial Bond \\ in South China
}





\section{DOWN TO EARTH}

The Territorial Bond in South China

EDITED BY DAVID FAURE

AND HELEN F. SIU

STANFORD UNIVERSITY PRESS

Stanford, California 1995 
Stanford University Press

Stanford, California

(C) 1995 by the Board of Trustees of the Leland Stanford Junior University

Printed in the United States of America

CIP data appear at the end of the book

Stanford University Press publications are distributed exclusively by Stanford

University Press within the United States, Canada, Mexico, and Central America; they are distributed exclusively by Cambridge University Press throughout the rest of the world. 